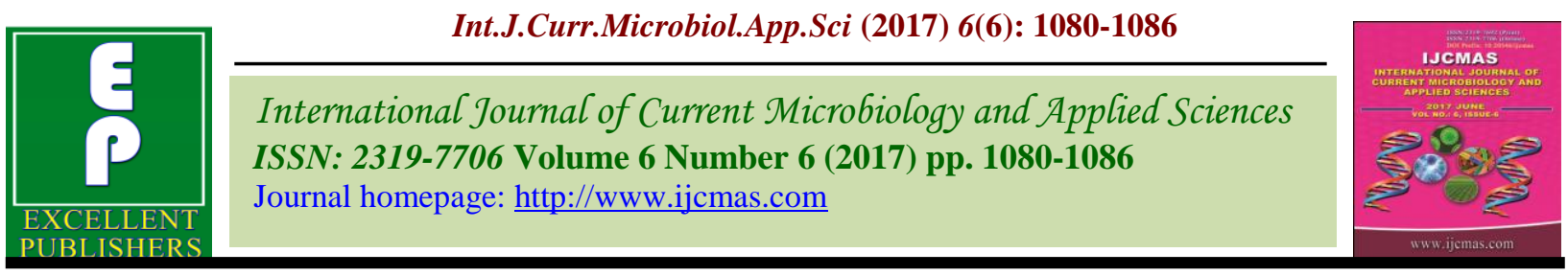

Original Research Article

https://doi.org/10.20546/ijcmas.2017.606.125

\title{
Evaluation of Potentiality of Mango (Mangifera indica l.) Cultivars for Physico-Chemical Attributes of Fruit
}

\author{
Tejraj Singh Hada* and Anil Kumar Singh
}

Department of Horticulture, Institute of Agricultural Sciences, Banaras Hindu University,

Varanasi-221005, (U.P.), India

*Corresponding author

\section{A B S T R A C T}

The main aim of the research was to investigate the physico-chemical attributes of different mango cultivars for both the years. Outcome of the present research work

Keywords

Cultivars,

Peel, Pulp,

Stone, Sugar.

Article Info

Accepted:

17 May 2017

Available Online:

10 June 2017 revealed that minimum stone length $(5.72 \mathrm{~cm})$ and stone breadth $(1.92 \mathrm{~cm})$ was recorded in Sepiya. Minimum peel weight was recorded in Gulabkhas (21.80 g) and minimum peel percentage $(9.01 \%)$ was observed in Mallika. Minimum stone weight was recorded in Gulabkhas $(25.26 \mathrm{~g})$ while, maximum pulp percentage $(82.71 \%)$, pulp weight $(316.99 \mathrm{~g})$ and minimum stone percentage $(8.25 \%)$ was recorded in Mallika. The maximum Edible/non-edible ratio was calculated in Mallika (4.82) and minimum ratio was obtained in Sepiya (1.65). Maximum total sugar percentage and Non-reducing percentage (14.58\%) was found in Amrapali (20.26\%). Maximum reducing sugar percentage was observed in Chausa $(6.39 \%) . H e n c e$, it can be concluded that Mallika was found superior in terms of pulp weight and fruit size.

\section{Introduction}

Mango (Mangifera indica L.) is an important fruit crop of India belonging to the family Anacardiaceae and acknowledged as "King of Fruits". It is the national fruit of India widely grown for its special features like high nutritive value, high productivity, processing potential, delicious taste and suitability in widely ecological amplitude. The mango is very nutritious and has great health benefits both, when eaten raw and as a ripe fruit. The fruit (ripe and unripe), bark, leaves, seed, root and even the smoke of burning mango leaves have healing properties. It is known to be a very good source of vitamins such as vitamin $\mathrm{C}$, thiamine, riboflavin, and niacin and $B$ - carotene. Mango contains numerous polyphenolic and phytonutrient compounds that have been shown to exhibit antioxidant properties. Mangoes can be considered as a good source of dietary antioxidants, such as ascorbic acid, carotenoids and phenolic compounds (Ribeiro et al., 2007). $\beta$-carotene is the most abundant carotenoid in several cultivars. These compounds are linked to anticancer and anti-inflammatory activities in the body.

Most of the north Indian varieties, viz. Dashehari, Langra, Chausa and Bombay Green are alternate bearer, while, most of the 
South Indian varieties bear regularly (Pandey and Dinesh, 2010). Low productivity is the resultant effect of alternate bearing, inadequate fruit set followed by heavy fruit drop. The initial fruit set in mango is directly related to the proportion of perfect flowers (Singh et al., 2015).

Physical characteristics of mangoes may be explained by the differences between varieties and methodologies of analysis, the ripeness of the fruit when harvested and climatic differences between the regions they were produced. The proportion between pulp, skin and endocarp is strongly influenced by the variety. There are many discrepancies concerning the physical and chemical characteristics of mangoes.

The proportion between pulp, skin and endocarp is strongly influenced by the variety and the soluble solids and titratable acidity ratio in mangoes. These characteristics are commonly used for evaluating flavour. Study of physical and chemical characteristics of mango trees can help to identify the best varieties for consumption and industrialization. In general, processing industry prefers mangoes with a higher yield of pulp, high soluble solid content and lack of fiber. For fresh consumption, consumers prefer fruit with low acidity, high soluble solid content and lack of fibers.

The fruit quality is attributed to its physical characteristics, especially the color of skin and fruit's shape and size. The quality attributes such as colour, shape, size and flavour should be maintained in newly evolved varieties so that India can increase its presence in the international market (Thulasiram et al., 2016).

However, all the cultivars are not suited for diverse climatic conditions. Some cultivars are preferred for their early or late ripening, while some are liked for the amount and quality of their fruit pulp.

However, in the same region, different environmental conditions at different years can affect maturity and quality of the fruit (Devilliers, 1998). A large number of mango varieties are being grown in India, most of them do not satisfy the requirements of an ideal commercial variety and fail in competition with other countries.

So, to work out physio-chemical attributes of different mango cultivars were taken for study. Therefore, evaluation of different mango cultivars for a given set of ecology is one of the pre-requisite for successful mango cultivation.

\section{Materials and Methods}

The present investigation was conducted at Horticulture Unit, Department of Horticulture, I. Ag. Sc., B.H.U., Varanasi, during 2014-2015 and 2015-2016. The experimental orchard comes under the Indogangetic alluvial track in eastern Uttar Pradesh in class II of land capability class and irrigated by tube well.

Varanasi is situated in eastern part of Utter Pradesh, which lies between $25^{\circ} 19^{\prime} 59^{\prime \prime}$ North latitude and $83^{\circ} 00^{\prime} 00^{\prime \prime}$ East longitude at an elevation of 76.80 meter above mean sea level.

The mean annual rainfall is about $850-1100$ $\mathrm{mm}$. The experiment was carried out on healthy and bearing of 20 years old trees.

The number of treatments were eleven and replicated thrice. Therefore, altogether thirtythree plants were selected for this investigation. Amrapali, Langra, Dashehari, Mallika, Chausa, Fazli, Bombai, Himsagar, Sepiya, Alphonso and Gulabkhascultivars 
were taken for study as treatments. The experiment was laid out in Randomized Block Design (RBD). The observations were recorded on physico-chemical attributes of fruit as length of stone $(\mathrm{cm})$, width of stone $(\mathrm{cm})$, peel weight $(\mathrm{g})$, peel percentage, pulp weight $(\mathrm{g})$, pulp percentage, stone weight $(\mathrm{g})$, stone percentage, Edible/non-edible ratio, total sugar $\%$, reducing sugar $\%$ and nonreducing sugar $\%$.

\section{Results and Discussion}

\section{Physico-chemical attributes of different mango cultivars}

\section{Stone size (Length and width)}

The minimum stone length $(5.72 \mathrm{~cm})$ and breadth $(1.92 \mathrm{~cm})$ was found in Sepiya and maximum stone length $(12.49 \mathrm{~cm})$ and breadth $(4.25 \mathrm{~cm})$ was observed in Mallika. Similar findings were also recorded by Bains and Dhillon (1999). Significant variation in stone length and width of different mango varieties were also reported by Kundu and Ghosh (1992) and Abirami et al., (2004). This variation in stone characteristics might be due to difference in environmental interaction and genetic composition.

\section{Weight of stone (g)}

Minimum stone weight was recorded in Gulabkhus (25.26 g) while, maximum weight was found in Chausa (42.96 g).

The present findings related to stone weight are also in accordance with the results of Jilani et al., (2010) and Anila and Radha (2003). Sarkar et al., (2001) reported that as the fruit weight and size in various cultivar differed, seed weight also varied within the cultivars. The results are confirmed by the findings of Majumder et al., (2011).

\section{Peel weight (g)}

Minimum peel weight was recorded in Gulabkhus (21.80 g) while, maximum weight was observed in Mallika (34.39 g). The present findings related to peel weight are also in accordance with the results of Anila and Radha (2003), Mitra et al., (2001) and Bakshi et al., (2013).

\section{Pulp weight (g)}

Maximum pulp weight per fruit was recorded in Mallika (316.99 g) while, minimum pulp weight was recorded in Sepiya (104.32 g). This confirms findings of previous workers Bains and Dhillon (1999), Kundu and Ghosh (1992) and Dhillon et al., (2004).

\section{Peel, pulp and stone content (\%)}

It clearly indicates that minimum peel percentage $(9.01 \%)$, maximum pulp percentage $(82.71 \%)$ and minimum stone percentage $(8.25 \%)$ was recorded in Mallika.

Maximum peel percentage $(18.71 \%)$, minimum pulp percentage $(61.51 \%)$ maximum stone percentage $(19.75 \%)$ was noted in Sepiya. Similar results were observed by Kher and Shama (2002), Sharma and Josan (1995).

The possible cause of variation might be due to the facts that mango is the most heterozygous crop or trait controlled by polygene, its variable nature is found from place to place.

According to Avilan et al., (1998), the ideal mango fruit benefits from high pulp content, small stone, thinnest peel and fibre absence. 
Int.J.Curr.Microbiol.App.Sci (2017) 6(6): 1080-1086

Table.1 Data regarding physico-chemical attributes of different mango cultivars

\begin{tabular}{lccccccccc}
\hline $\begin{array}{l}\text { Treatment } \\
\text { (Cultivars) }\end{array}$ & $\mathbf{2 0 1 4 - 1 5}$ & $\mathbf{2 0 1 5 - 1 6}$ & $\begin{array}{c}\text { Pooled } \\
\text { mean }\end{array}$ & $\mathbf{2 0 1 4 - 1 5}$ & $\mathbf{2 0 1 5 - 1 6}$ & $\begin{array}{c}\text { Pooled } \\
\text { mean }\end{array}$ & $\mathbf{2 0 1 4 - 1 5}$ & $\begin{array}{c}\text { 2015-16 } \\
\text { Pooled } \\
\text { mean }\end{array}$ \\
\hline Amrapali & 31.79 & 30.02 & 30.90 & 20.93 & 26.27 & 23.60 & 167.28 & 165.05 & 166.16 \\
Langra & 29.12 & 33.77 & 31.45 & 31.55 & 32.80 & 32.18 & 242.93 & 256.59 & 249.76 \\
Dashehari & 26.76 & 25.13 & 25.95 & 27.92 & 28.53 & 28.23 & 123.15 & 116.17 & 119.66 \\
Mallika & 31.59 & 31.20 & 31.40 & 32.75 & 36.03 & 34.39 & 317.88 & 316.10 & 316.99 \\
Chausa & 45.48 & 40.43 & 42.96 & 27.84 & 24.77 & 26.30 & 201.98 & 222.80 & 212.39 \\
Fazli & 32.49 & 34.17 & 33.33 & 31.66 & 32.90 & 32.28 & 274.26 & 285.77 & 280.01 \\
Bombai & 27.36 & 28.99 & 28.18 & 35.80 & 32.93 & 34.37 & 231.49 & 246.58 & 239.04 \\
Himsagar & 34.91 & 38.57 & 36.74 & 24.68 & 23.45 & 24.07 & 189.82 & 197.31 & 193.57 \\
Sepiya & 31.75 & 33.23 & 32.49 & 30.57 & 31.03 & 30.80 & 109.58 & 99.07 & 104.32 \\
Alphonso & 31.56 & 33.60 & 32.58 & 30.12 & 31.07 & 30.59 & 223.99 & 217.83 & 220.91 \\
Gulabkhas & 25.18 & 25.33 & 25.26 & 24.71 & 18.88 & 21.80 & 175.44 & 189.12 & 182.28 \\
SEm \pm & 0.80 & 0.65 & 0.61 & 1.13 & 0.52 & 1.13 & 12.10 & 9.02 & 10.20 \\
C.D. at 5\% & 2.36 & 1.92 & 1.80 & 3.33 & 1.54 & 3.33 & 35.71 & 26.62 & 30.09
\end{tabular}

Table.2 Data regarding physico-chemical attributes of different mango cultivars

\begin{tabular}{lccccccccc}
\hline $\begin{array}{l}\text { Treatment } \\
\text { (Cultivars) }\end{array}$ & $\mathbf{2 0 1 4 - 1 5}$ & $\begin{array}{c}\text { Stone \% } \\
\mathbf{2 0 1 5 - 1 6}\end{array}$ & $\begin{array}{c}\text { Pooled } \\
\text { mean }\end{array}$ & $\mathbf{2 0 1 4 - 1 5}$ & $\begin{array}{c}\text { Peel \% } \\
\mathbf{2 0 1 5 - 1 6}\end{array}$ & $\begin{array}{c}\text { Pooled } \\
\text { mean }\end{array}$ & $\mathbf{2 0 1 4 - 1 5}$ & $\begin{array}{c}\text { Pulp \% } \\
\text { 2015 }\end{array}$ & $\begin{array}{c}\text { Pooled } \\
\text { mean }\end{array}$ \\
\hline Amrapali & 14.52 & 13.56 & 14.04 & 9.60 & 12.04 & 10.82 & 75.88 & 74.55 & 75.22 \\
Langra & 9.60 & 10.48 & 10.04 & 10.40 & 10.70 & 10.55 & 80.00 & 79.35 & 79.68 \\
Dashehari & 15.08 & 14.79 & 14.94 & 15.69 & 16.52 & 16.11 & 69.23 & 68.40 & 68.81 \\
Mallika & 8.30 & 8.19 & 8.25 & 8.63 & 9.40 & 9.01 & 83.06 & 82.36 & 82.71 \\
Chausa & 16.64 & 14.05 & 15.35 & 10.24 & 8.73 & 9.48 & 73.12 & 77.33 & 75.23 \\
Fazli & 9.68 & 9.75 & 9.71 & 9.44 & 9.79 & 9.62 & 80.88 & 80.83 & 80.86 \\
Bombai & 9.45 & 9.54 & 9.50 & 12.36 & 11.13 & 11.75 & 78.19 & 79.65 & 78.92 \\
Himsagar & 14.38 & 15.17 & 14.78 & 10.35 & 9.88 & 10.12 & 75.26 & 75.60 & 75.43 \\
Sepiya & 19.05 & 20.44 & 19.75 & 18.28 & 19.15 & 18.71 & 62.67 & 60.34 & 61.51 \\
Alphonso & 11.10 & 11.90 & 11.50 & 10.73 & 10.92 & 10.82 & 78.17 & 77.09 & 77.63 \\
Gulabkhas & 11.42 & 10.95 & 11.19 & 10.96 & 8.17 & 9.56 & 77.62 & 80.91 & 79.26 \\
SEm \pm & 0.76 & 0.41 & 0.54 & 0.75 & 0.58 & 0.63 & 1.40 & 0.80 & 1.04 \\
C.D. at 5\% & 2.24 & 1.23 & 1.60 & 2.23 & 1.71 & 1.87 & 4.14 & 2.36 & 3.07 \\
\hline
\end{tabular}


Table.3 Data regarding physico-chemical attributes of different mango cultivars

\begin{tabular}{lccccccccc}
\hline $\begin{array}{l}\text { Treatment } \\
\text { (Cultivars) }\end{array}$ & $\mathbf{2 0 1 4 - 1 5}$ & $\mathbf{2 0 1 5 - 1 6}$ & $\begin{array}{c}\text { Pooled } \\
\text { mean }\end{array}$ & $\mathbf{2 0 1 4 - 1 5}$ & $\mathbf{2 0 1 5 - 1 6}$ & $\begin{array}{c}\text { Pooled } \\
\text { mean }\end{array}$ & 2014-15 & 2015-16 & $\begin{array}{c}\text { Pooled } \\
\text { mean }\end{array}$ \\
\hline Amrapali & 7.60 & 6.87 & 7.24 & 2.39 & 2.65 & 2.52 & 3.25 & 2.93 & 3.09 \\
Langra & 7.42 & 8.02 & 7.72 & 3.15 & 3.37 & 3.26 & 4.01 & 3.89 & 3.95 \\
Dashehari & 6.98 & 7.23 & 7.11 & 2.63 & 2.58 & 2.61 & 2.25 & 2.16 & 2.21 \\
Mallika & 12.34 & 12.64 & 12.49 & 4.40 & 4.10 & 4.25 & 4.94 & 4.71 & 4.82 \\
Chausa & 7.35 & 8.12 & 7.74 & 3.79 & 3.50 & 3.64 & 2.76 & 3.43 & 3.09 \\
Fazli & 10.14 & 10.65 & 10.40 & 4.02 & 3.70 & 3.86 & 4.28 & 4.26 & 4.27 \\
Bombai & 7.09 & 8.16 & 7.63 & 3.13 & 3.07 & 3.10 & 3.66 & 3.97 & 3.82 \\
Himsagar & 7.67 & 7.23 & 7.45 & 3.10 & 3.34 & 3.22 & 3.22 & 3.19 & 3.20 \\
Sepiya & 5.90 & 5.54 & 5.72 & 1.86 & 1.99 & 1.92 & 1.77 & 1.54 & 1.65 \\
Alphonso & 6.03 & 6.73 & 6.38 & 3.28 & 2.91 & 3.09 & 3.64 & 3.38 & 3.51 \\
Gulabkhas & 6.05 & 7.69 & 6.87 & 2.94 & 2.96 & 2.95 & 3.54 & 4.28 & 3.91 \\
SEm \pm & 0.32 & 0.24 & 0.20 & 0.35 & 0.20 & 0.22 & 0.52 & 0.28 & 0.29 \\
C.D. at 5\% & 0.94 & 0.73 & 0.60 & 1.02 & 0.59 & 0.66 & 1.08 & 0.82 & 0.85 \\
\hline
\end{tabular}

Table.4 Data regarding physico-chemical attributes of different mango cultivars

\begin{tabular}{lccccccccc}
\hline \multirow{2}{*}{$\begin{array}{l}\text { Treatment } \\
\text { (Cultivars) }\end{array}$} & $\mathbf{2 0 1 4 - 1 5}$ & $\mathbf{2 0 1 5 - 1 6}$ & $\begin{array}{c}\text { Pooled } \\
\text { mean }\end{array}$ & $\mathbf{2 0 1 4 - 1 5}$ & $\mathbf{2 0 1 5 - 1 6}$ & $\begin{array}{c}\text { Pooled } \\
\text { mean }\end{array}$ & $\begin{array}{c}\text { No14-15 } \\
\text { 2014cing sugars }(\%)\end{array}$ & $\begin{array}{c}\mathbf{2 0 1 5 - 1 6} \\
\text { Pooled } \\
\text { mean }\end{array}$ \\
\hline Amrapali & 19.95 & 20.57 & 20.26 & 6.01 & 5.35 & 5.68 & 13.94 & 15.22 & 14.58 \\
Langra & 17.57 & 16.45 & 17.01 & 4.53 & 5.12 & 4.83 & 13.04 & 11.33 & 12.18 \\
Dashehari & 16.49 & 15.98 & 16.24 & 3.33 & 3.92 & 3.63 & 13.16 & 12.06 & 12.61 \\
Mallika & 17.54 & 16.95 & 17.25 & 4.60 & 3.78 & 4.19 & 12.94 & 13.17 & 13.06 \\
Chausa & 18.58 & 17.33 & 17.95 & 5.82 & 6.96 & 6.39 & 12.76 & 10.37 & 11.57 \\
Fazli & 15.05 & 15.39 & 15.22 & 3.76 & 3.81 & 3.79 & 11.29 & 11.58 & 11.43 \\
Bombai & 15.44 & 17.11 & 16.28 & 5.58 & 6.38 & 5.98 & 9.86 & 10.74 & 10.30 \\
Himsagar & 16.00 & 15.37 & 15.69 & 5.22 & 5.75 & 5.49 & 10.78 & 9.62 & 10.20 \\
Sepiya & 13.47 & 14.63 & 14.05 & 3.11 & 3.38 & 3.25 & 10.36 & 11.25 & 10.80 \\
Alphonso & 14.81 & 15.51 & 15.16 & 3.73 & 4.35 & 4.04 & 11.08 & 11.16 & 11.12 \\
Gulabkhas & 15.48 & 16.50 & 15.99 & 5.01 & 5.92 & 5.47 & 10.47 & 10.58 & 10.52 \\
SEm \pm & 0.34 & 0.31 & 0.23 & 0.23 & 0.26 & 0.17 & 0.40 & 0.33 & 0.25 \\
C.D. at 5\% & 1.01 & 0.92 & 0.70 & 0.70 & 0.77 & 0.51 & 1.19 & 0.99 & 0.74 \\
\hline
\end{tabular}

The variation in pulp, peel and stone content was also recorded by Kundu and Ghosh (1992), Singh and Yadav (1994), Singh (2002), Dhillon et al., (2004), Dutta et al., (2008) and Modesto et al., (2016). This variation in pulp, peel and stone content might be due to difference in fruit and stone size, genetic makeup, rate of photosynthetic assimilation \& translocation and effect of different growth hormone. The differences in percentage of pulp, peel and stone from place to place are natural because environmental and seasonal variations were observed by earlier workers (Kumar and Singh, 2005; Chatterjee et al., 2005 and Sinha et al., 2007). The pulp percentage depends on the diversion of food assimilates towards mesocarp.

\section{Edible/Non - edible ratio}

The maximum Edible/non-edible ratio was calculated in Mallika (4.82). The present findings related to varied edible: non-edible ratio was also in accordance with the results of Chatterjee et al., (2005) and Chanana et al., 
(2005).

\section{Sugars (Total, reducing and non-reducing)}

Maximum total sugar percentage was found in Amrapali (20.26\%), whereas, the minimum was noted in Sepiya (14.05\%). These results partially agreed with the findings of Sengupta $e t$ al., (2006). This difference might be due to varietal difference as well as growing conditions. Maximum reducing sugar percentage was observed in Chausa (6.39\%) and minimum percentage in this respect was noted in Sepiya $(3.25 \%)$. The results are in agreement with that of Chaudhari et al., (1997). Amrapali was at the top with a value of 14.58 per cent non-reducing sugar and minimum percentage was recorded in Himsagar (10.20\%). These findings are confirmed by the findings of Uddin et al., (2006), Bakshi et al., (2013) and Shafique et al., (2006). The increase in total sugars might be the conversion of starch and polysaccharides into soluble sugars.

Based on the present findings it can be concluded that the mango cultivar Mallika was found superior in terms of pulp weight and edible/non -edible ratio. Amrapali was superior in terms of qualitative parameters such as total and non-reducing sugarswhile, Chausa was found superior in terms of reducing sugar.

\section{References}

Abirami, K., Nachegowda, V. and Reddy Y. T.N. Physico-chemical attributes of certain poly-embryonic varieties of mango. South Indian Horticult., 52(1/6): 291-296.

Anila, R. and Radha, T. 2003. Physico-chemical analysis of mango varieties under Kerala conditions. J. Trop. Agri., 41(1/2): 20-22.

Avilan, L., Rodríguez, M. and Ruiz, J. 1998. El Cultivodel Manguero en Venezuela. FONAIAP Edition, Maracay, Venezuela, pp. 59-92.

Bains, K.S. and Dhillon, W.S. 1999. Physicochemical characters of different mango
(Mangiferaindica L.) cultivars grown under sub-montaneous conditions of Punjab. Haryana J. Horticult. Sci., 28(3/4): 174-176.

Bakshi, P., Kumar, R., Jasrotia, A. and Sharma, A. 2013. Variability in physico-chemical and sensory attributes of mango genotypes under rainfed conditions of Shivalik foothills of Himalayas. Asian J. Horticult., 8(1): 39-42.

Chanana, Y.R., Josan, J.S. and Arora, P.K. 2005. Evaluation of some mango cultivars under North Indian conditions. International Conference on Mango and Date Palm: Culture and Export, 20- 23rd June, pp. 34-38.

Chatterjee, D., Maurya, K.R. and Mandal, M. P. 2005. Physico-chemical characteristics of mango (Mangiferaindica L.) hybrids in Bihar. Orissa J. Horticult., 33(2): 57-60.

Chaudhary, S.M., Patil, B.T. and Desai, U.T. 1997. Performance of south Indian mango varieties under semi-arid region of Maharashtra. J. Maharashtra Agri. Univ., 22(1): 72-74.

Devilliers, E.A. 1998. The cultivation of mango, Institute of Tropical and Subtropical Fruits. pp. 28-30.

Dhillon, W.S., Sharma, R.C. and Kahlon, G.S. 2004. Evaluation of some mango varieties under Punjab conditions. Haryana $J$. Horticult. Sci., 33(3/4): 157-159.

Dutta, P., Chakraborty, K., Roy, S.K. and Samanta, A. 2008. Physico-chemical qualities and storage behaviour of some promising mango hybrids grown in new alluvial zone of West Bengal. Haryana J. Horticult. Sci., 37(3/4): 247-248.

Jilani, M.S., Bibi, F., Waseem, K. and Khan, M.A. 2010. Evaluation of physicochemical characteristics of mango (Mangifera indica L.) cultivars. J. Agri. Res., 48(2): 201-207.

Kher, R. and Sharma, R.M. 2002. Performance of some mango cultivars under subtropical rainfed region of Jammu. Haryana J. Horticultural Sci., 31(1/2): 89. 
Kumar, R. and Singh, S. 2005. Evaluation of mango genotypes for flowering, fruiting and fruit quality attributes. The Orissa $J$. Horticulture, 33(1): 77-79.

Kundu, S. and Ghosh, S.N. 1992. Studies on physico-chemical characteristics of mango cultivars grown in lateritic tract of West Bengal. Haryana J. Horticult. Sci., 21(3/4): 129-134.

Majumder, D.A.N., Hassan, L., Rahim, M.A. and Kabir, M.A. 2011. Studies on physiomorphology, floral biology and fruit characteristics of mango. $J$. Bangladesh Agri. Univ., 9(2): 187-199.

Mitra, S., Kundu, S. and Mitra, S.K. 2001. Evaluation of local strains of mango (Mangifera indica) grown in West Bengal. Indian J. Agri. Sci., 71(7): 466468.

Modesto, J.H., Leonel, S., Segantini, D.M., Souza, J.M.A. and Ferraz, R.A. 2016. Qualitative attributes of some mango cultivars fruits. Australian J. Crop Sci., 10(4): 565-570.

Pandey, S.N. and Dinesh, M.R. 2010. Mango, Indian Council of Agricultural Research, New Delhi, pp. 30-97.

Ribeiro, S.M.R., Queiroz, J.H., Queiroz, M.E.L.R., Campos, F.V.M. and Santana, H.M.P. 2007. Antioxidant in mango (Mangifera indicaL.) pulp. Plant Foods Human Nutr., 62: 13-17.

Sarkar, S.K., Gautham, B., Neerja, G. and Vijaya, N. 2001. Evaluation of mango hybrids under Telangana region of Andhra Pradesh. Horticult. J., 14(1): 1321.

Sengupta, S., Munsi, P.S. and Pujari, M.M. 2006. Studies on the performance and prospect of some promising mango hybrids in the Gangetic plains of Eastern Bihar. Orissa J. Horticult., 34(2): 74-77.

Shafique, M.Z., Ibrahim, M., Helali, M.O.H. and Biswas, S.K. 2006. Studies on the physiological and biochemical composition of different mango cultivars at various maturity levels. Bangladesh $J$. Sci. Indust. Res., 4(1/2): 101-108.

Sharma, J.N. and Josan, J.S. 1995. Performance of mango cultivars under arid-irrigated regions of Punjab. Indian J. Horticult., 52(3): 179-181.

Singh, A., Singh, C.P. and Singh, A.K. 2015. Flowering behaviour of mango genotypes under tarai conditions of uttarakhand. Int. J. Basic and Appl. Agri. Res., 13(3): 400406.

Singh, M. and Yadav, K.S. 1994. Evaluation of physico-chemical traits in different varieties of mango (Mangiferaindica L.). Crop Res., 8(1): 86-94.

Singh, S. 2002. Evaluation of mango cultivars for their flowering, fruiting and fruit quality attributes. Progressive Horticulture, 34(2): 240-243.

Sinha, B., Singh, U.K. and Kumar, N. 2007. Fruit quality of leading late varieties of mango. The Orissa J. Horticulture, 35(2): 84-86.

Thulasiram, R., Alagumani, T. and Duraisamy, M.R. 2016. Preferences of quality attributes for mango export: a conjoint analysis approach. Int. Res. J. Agri. Economics and Statistics, 7(1): 42-47.

Uddin, M.Z., Rahim, M.A., Alan, M.A., Barman, J.C. and Wadud, M.A. 2006. A study on biochemical characteristic of different mango germplasm grown in the climatic conditionof Mymen singh. Int. J. Sustainable Crop Production, 1(2): 1619.

\section{How to cite this article:}

Tejraj Singh Hada and Anil Kumar Singh. 2017. Evaluation of Potentiality of Mango (Mangifera indica L.) Cultivars for Physico-Chemical Attributes of Fruit. Int.J.Curr.Microbiol.App.Sci. 6(6): 1080-1086. doi: https://doi.org/10.20546/ijcmas.2017.606.125 